\section{Этнокультура и экономика: синергия возможностей ${ }^{\star}$}

Ю.В. попков, доктор философских наук, Институт философии и права СО РАН, Новосибирский государственный технический университет. E-mail: yuripopkov54@mail.ru

Е.А. ТЮГАШЕВ, кандидат философских наук, Новосибирский национальный исследовательский государственный университет, Новосибирск.

E-mail: filosof10@yandex.ru

Представлен обзор концептуальных предпосылок исследования связи этнокультурного разнообразия с социальными механизмами экономической жизни. Выделены идеи классиков политической экономии по заявленной теме с акцентом на нациецентризме, фиксирующем определяющее влияние природно-климатических условий, типа хозяйства, культурной специфики и особенностей национального характера населения на хозяйственную специализацию наций. Этнокультурное разнообразие рассматривается как дополнительный экономический ресурс. Выделены эколого-экономические представления о стабильности и продуктивности экологических сообществ, которые использовань для интерпретации роли этнокультурного разнообразия в социально-экономическом развитии межэтнических сообществ, в обеспечении их социальной стабильности и экономической продуктивности. На основе анализа территориально локализованной экономики как межэтнического сообщества сделан вывод о благоприятном воздействии этнокультурного разнообразия на экономическое развитие и межэтнические отношения при условии успешной интеграции иноэтнокультурных групп в принимающее сообщество.

Ключевые слова: нация, этнос, этническое разнообразие, этнокультура, этноэкономика, этническая экология, антропоэкология, межэтническое сообщество

\section{Постановка проблемы}

В условиях глобализации уходит в прошлое политика контролируемой миграции, использующая фильтры по критериям образования, профессии, имущественной обеспеченности, этноконфессиональной предпочтительности. Многие иммигранты не склонны ассимилироваться в принимающие общества, формируют этнические анклавы и секторы этнической экономики, социальные механизмы которой существенно отличаются от рынка, регулируемого государством. Демографические последствия аккультурации мигрантов в национальных сообществах напоминают

"Работа выполнена в рамках раздела «Этнокультурные механизмы пространственного развития Сибири» междисциплинарного проекта «Экономико-географические, этнокультурные и историко-демографические механизмы пространственного развития Сибири» Комплексной программы фундаментальных научных исследований СО РАН II.1. о популяционной катастрофе и грядущем замещении коренного населения иноэтничным.

В ситуации проявленных симптомов кризиса национальной государственности усиливается этническая фрагментация, и в регионах формируется потенциал этнокультурных революций, подрывающих утопию единства национальной государственности.

Наблюдающийся этнический ренессанс пробудил научный интерес к изучению возможностей конструктивного использования потенциала различных этнокультур в интересах экономики. В настоящей статье решается задача выявления концептуальных предпосылок исследования и эффектов взаимосвязи этнокультурного и экономического развития, а также обоснования новых подходов к изучению межэтнических взаимодействий как системного механизма экономической жизни наций.

\section{Фокус нации в политической экономии}

Классическая экономическая наука до середины XX века не занималась этничностью как экономически значимым феноменом. Но классикам экономической мысли был известен феномен наций и эмпирически очевиден факт различий в экономическом быте разных народов.

В знаменитой работе шотландского этика и экономиста А. Смита «Исследование о природе и причинах богатства народов (An Inquiry into the Nature and Causes of the Wealth of Nations, 1776) нация представлена в качестве основного субъекта обогащения. В целом эта позиция была не нова, но впервые так ясно выражена. Ведь и меркантилисты, и физиократы заботились об обогащении национальных государств, а А. Смит акцентировал внимание на обогащении именно наций, так как, отстаивая в интересах шотландцев принцип свободной торговли, он фактически выступал против протекционистской политики Великобритании.

А. Смит дифференцировал народы по типу хозяйства на охотничьи и пастушеские, земледельческие, промышленные и торговые, утверждая, что уже на охотничьей стадии возникает устойчивое разделение труда, стимулирующее человека развивать до совершенства природные дарования в конкретной специальности. По его оценке, люди и народы мало различаются своими естественными способностями, пригодны для всех видов 
хозяйственной деятельности и легко переучиваются. В то же время ученый отмечал, что традиции древних египтян и древних индусов фактически запрещали заниматься мореплаванием, вынуждая их для вывоза избыточного продукта обращаться к другим народам, специализирующимся на морской торговле [Смит, 1962. С. 494].

Международное разделение труда обусловливало, по А. Смиту, и различие национальных характеров: «... Нации, которые, подобно Франции или Англии, состоят в значительной мере из землевладельцев и земледельцев, могут обогащаться трудом и потреблением. Напротив, страны или города, которые, подобно Голландии и Гамбургу, состоят преимущественно из купцов, ремесленников и мануфактуристов, могут богатеть только посредством бережливости и воздержания. Как различны интересы наций, так различен и общий характер их народов. У наций первого рода естественными чертами характера бывают щедрость, откровенность и веселость, тогда как вторые отличаются скупостью, мелочностью и эгоизмом и не любят никаких общественных развлечений и удовольствий» [Смит, 1962. С. 484]. Таким образом, разделение труда между нациями настолько упрочилось, что закрепилось в национальном характере и стало самостоятельным фактором хозяйственной деятельности.

Д. Рикардо также признавал выгодность международного разделения труда, выделяя нации земледельческие, промышленные, торговые и др. Английский экономист поддерживал позицию «Британской энциклопедии», авторы которой полагали, что национальный характер обеспечивает особенные преимущества в экономике [Рикардо, 1955. С. 221].

Дж. С. Милль приводил сведения по сравнительной характеристике «природных» (понятливость, сметливость, сообразительность) и нравственных (порядочность, умеренность, честность, бережливость) качеств английских рабочих и рабочих различных национальностей континентальной Европы [Милль, 1980. С. 216218]. Он заключал, что национальные особенности мышления и нравственности работников ощутимо влияют на эффективность и качество труда. Например, недостаточная сообразительность требует дополнительного времени на разъяснения, а возможная недобросовестность влечет значительные затраты на надзор или проверку выполненной работы.
Заметный нациецентризм политической экономии отчетливо проявился в национальной (исторической) школе немецкой политэкономии. Ф. Лист в труде «Национальная система политической экономии» (1841) не вполне справедливо, на наш взгляд, обвинив предшествующую экономическую мысль в космополитизме, выдвинул доктрину национальной экономии, или экономии наций (в противоположность экономии общества или человечества). Данная доктрина включала: а) эмпирическое представление о бесконечном разнообразии наций; б) принцип приоритета национальности в экономической жизни; в) положение о сохранении, развитии и совершенствовании национальных особенностей как главной цели народов; г) учение о развитии производительных сил народов как основы их богатства; д) утверждение о различных требованиях к рабочей силе в странах умеренного и жаркого климатических поясов и вытекающих из этого различий в развитии производительных сил наций как основы международного разделения труда. В связи с этим он говорил о различных путях, которыми страны достигают цивилизации.

Ф. Лист отмечал, что Англия своим богатством обязана исконному чувству свободы и права, энергии и нравственности народа [Лист, 2005. С. 69]. Основу возрождения Германии он видел в таких чертах немецкого характера, как любовь к труду и порядку, бережливость и умеренность, настойчивость и выдержка, рассудительность и искреннее стремление к лучшему [Лист, 2005. С. 89].

Сближение наций Ф. Лист рассматривал как конечную цель экономического развития. Он придавал большое значение межрасовым и межэтническим бракам, все более распространявшимся благодаря привлечению сельского населения в крупные промышленные города: «Мне кажется, что по той же причине народы, происшедшие от частого, так сказать, освежения всей нации подобными скрещиваниями, превосходят другие нации силой ума и характера, крепостью и красотой тела» [Лист, 2005. С. 184]. Этноконфессиональные чистки (изгнание евреев и морисков из Испании, гугенотов из Франции) исследователь оценивал как ключевой фактор экономического упадка этих стран. В качестве положительного момента он рассматривал приглашение специалистов и направление работников в другие страны на обучение. 
Таким образом, политическая экономия была сфокусирована на проблеме обогащения наций (народов), которые рассматривались как основные соперники в экономическом развитии от охотничьей до промышленной стадий цивилизации. С точки зрения классических представлений, сотрудничество наций осуществляется в международном разделении труда, их хозяйственную специализацию определяют природно-климатические условия, достигнутая стадия развития, культурная специфика и особенности национального характера населения. Неравномерность экономического развития наций стимулирует миграции, а этнокультурное разнообразие становится дополнительным экономическим ресурсом.

\section{Этноэкономика и этнокультурное разнообразие}

Еще в 1970-е годы постановка этнографами вопроса о связи этноса и экономики воспринималась как необычная [Козлов, 1970]. Но уже в 1990-е годы за рубежом как самостоятельное направление исследований оформилась этническая экономика [Light, 1994], а в отечественной науке было заявлено о выделении экономической этнологии [Семенов, 1993].

Этническая экономика (или этноэкономика) - это термин, используемый для обозначения как направления экономических исследований, так и изучаемого в этих исследованиях этнического аспекта экономической жизни. Например, К.В. Павлов определяет этноэкономику как науку о взаимосвязи и взаимовлиянии, которые оказывают традиции, обычаи, культура, психология, идеология, религиозные воззрения различных этносов на характер и уровень развития производительных сил и производственных отношений [Павлов, 2016. С. 14].

Важно подчеркнуть, что в данном определении утверждается вторичная, подчиненная и опосредствующая роль экономических процессов по отношению к этническим. В этом К. В. Павлов следует идее нациентризма классической политической экономии.

В этноэкомических исследованиях зафиксированы следующие формы этнического аспекта экономической жизни:

- традиционные для этноса виды жизнеобеспечения и хозяйства, возрождаемые народные промыслы;

- этническая специфика экономического поведения и деловых культур;
- этническое разделение труда и этническое доминирование в определенных профессиях и секторах экономики;

- этноэкономический менеджмент при формировании многонациональных трудовых коллективов;

- этнический бизнес и предпринимательство;

- этноэкономическая стратификация с созданием привилегий и преференций для представителей одного народа и дискриминацией представителей других народов;

- этнические анклавы и этнические секторы экономики, включающие комплекс видов хозяйственной деятельности, ориентированный на воспроизводство этнической группы;

- национальная экономика как этногомогенное или этногетерогенное сообщество.

Большой интерес вызывает влияние этнокультурного разнообразия на экономический рост. С одной стороны, констатируется успешность этнически наиболее гомогенных экономик (Норвегии и Японии) и экономический провал этнически наиболее гетерогенных государств Африки. С другой стороны, установлено, что ряд экономически развитых стран, регионов и крупных городов имеют высокий уровень этнокультурного разнообразия. Правда, не исключено, что данная взаимосвязь объясняется миграционной привлекательностью этих территорий.

Оценивая благоприятные условия использования экономических ресурсов этнокультурного разнообразия, И. Цапенко указывает на синергетический эффект комплементарности стилей мышления и компетенций носителей разных традиций и менталитетов [Цапенко, 2016. С. 42]. По ее мнению, интернациональный коллектив особенно полезен для организаций, включенных в интенсивные международные связи. Оптимальный с экономической точки зрения уровень этнокультурного многообразия складывается в интернациональных коллективах, в которых участвуют сотрудники с общими или хотя бы близкими культурными ценностями. Рост культурного разнообразия может иметь благотворные экономические последствия лишь при сотрудничестве, позитивном взаимодействии представителей разных этнокультур и при условии успешной интеграции этнических и конфессиональных меньшинств в принимающие сообщества. В целом исследователь подчеркивает необходимость эффективного управления культурным разнообразием, 
создающего условия для наиболее полной реализации экономического потенциала мигрантов.

И. Цапенко приводит сведения о том, что на материале Великобритании выявлена следующая зависимость между изменением доли представителей этнокультурных меньшинств в составе руководителей/собственников предприятий и его экономическими показателями. Экспортные доходы предприятия возрастают, пока удельный вес членов диаспор не достигнет 47\% состава руководящей команды. Аналогично для увеличения оборота фирмы такая пороговая доля составила 44\% [Цапенко, 2016. С. 43]. По ее мнению, иммигрантские команды управленцев начинают сталкиваться с различными сложностями и ограничениями, что ухудшает показатели деятельности фирм. Таким образом, даже сборные команды из высокопрофессиональных иммигрантов требуют эффективного контроля со стороны представителей коренного этноса.

Интересен зафиксированный в этноэкономических исследованиях феномен этнофрагментации, т.е. раскола национального государства на конфликтующие этнические группы. Показано, что в Африке во второй половине ХХ века большинство этнополитических конфликтов происходило в этнофрагментированных странах с развитыми добывающими секторами экономики (особенно связанными с экспортом сырья), с большой плотностью населения при слабом правительстве, не способном обеспечить контроль над армией и доступом к оружию [Камалова, 2013. С. 143]. Соответственно, отмечалось, что в авторитарных и демократических государствах отрицательное влияние этнической гетерогенности на экономический рост существенно меньше [Буфетова и др., 2017. С. 144]. Следовательно, в условиях этнокультурного разнообразия необходимо либо верховенство доминантной этнокультуры, либо такой механизм взаимодействия этнокультур в национальном сообществе, который его консолидирует.

Примечательно, что такие этнически гомогенные государства, как Норвегия и Япония, характеризуются низким уровнем поляризации населения по уровню доходов. Возможно, именно этническая гомогенность является важной предпосылкой консолидированности этносов, а это, в свою очередь, обеспечивает высокую экономическую продуктивность. Вместе с тем известно, что экономики этих государств не вполне устойчивы. Доходы бюджета Норвегии сильно зависят от добычи нефти, а Япония сталкивается с проблемой старения населения, то есть с демографической неустойчивостью. Потому актуальным представляется изучение проблемы связи этнокультурного разнообразия с устойчивостью экономического роста.

\section{Уроки экологии}

Для обсуждения означенной проблемы полезно описание территориально локализованной экономики как межэтнического сообщества, в котором взаимодействуют различные этнокультуры. В этом смысле этнокультурное разнообразие можно сопоставить с биоразнообразием и, соответственно, использовать экологические представления для анализа межэтнического сообщества как регионального антропогеоценоза. В этом случае эвристична аналогия между этнокультурами и биологическими видами, а точнее - поскольку объектом являются внутривидовые отношения - аналогия с экологически вариабельными этнотипами. Такую аналогию фактически проводил Л.Н. Гумилев, описывавший существенную взаимосвязь этноса и ландшафта.

Это позволило сформировать этническую экологию как самостоятельное исследовательское направление. Один из его основоположников В.И. Козлов писал о том, в частности, что на обширной территории с разнообразными ландшафтами различные по своим системам жизнеобеспечения этносы находят для себя отдельные экологические ниши и могут долгое время сосуществовать, как, например, эвенки, буряты и русские в Забайкалье [Козлов, 1994. С. 217]. По его оценке, наиболее чувствительны к вселению иноэтничных групп те аборигенные группы, которые специализированы на присваивающем хозяйстве, так как даже незначительная хозяйственная активность мигрантов может привести к нарушению экологического баланса и деградации антропогеоценоза.

В экологии по отношению к инвазионным видам, вторгающимся в экосистему, замечено, что на начальном этапе внедрения на новые территории они осваивают ресурсы, недоиспользуемые аборигенными видами, а на следующем - вступают в конкуренцию за используемые теми ресурсы. Конкурентное превосходство выражается в высокой продуктивности, устойчивости и простоте размножения. Эффект высокой численности потомства активно 
натурализующихся видов получил название «давление диаспор» [Виноградова и др., 2015. С. 37].

Экологические преимущества биоразнообразия обычно фиксируются в следующих эффектах, которые, на наш взгляд, аналогично проявляются в рамках этнокультурного разнообразия:

- максимальная эффективность специализированных видов в использовании источников и форм ресурсов;

- многообразие организмов, выполняющих сходные функции в экосистемах, повышает надежность и устойчивость экосистем за счет многократного дублирования потоков в пищевых цепях и заполнения освободившихся по тем или иным причинам экологических ниш аналогичными видами;

- повышение общей стабильности сообществ за счет более или менее равномерного распределения эффекта воздействия внешних факторов между отдельными видами;

- повышение индивидуальной устойчивости и пластичности членов сообщества в условиях насыщенной и разнообразной конкурентной среды;

- преимущественное появление эволюционно существенных новообразований.

Подчеркивается, что в природе отбираются, в конечном счете, не более продуктивные, а более экономные сообщества, способные минимизировать потери и максимально замкнуть круговорот [Горшков, 1995. С. 22].

Сообщества с малым биоразнообразием встречаются на островах, в ряде естественных ландшафтов (пустыня, сухая степь, тундра), а также в агробиоценозах. В таких сообществах виды, адаптированные к ландшафту, становятся доминантными и достигают большой численности. Вместе с тем именно такие сообщества неустойчивы, поскольку численность доминирующего вида подвержена значительным флуктуациям.

Вместе с тем и биоразнообразие динамично. В стабильных экосистемах виды предельно специализированы, что при изменении внешних условий ведет к ломке структуры. Так, в палеоэкологии кризисные ситуации диагностируются по критерию падения разнообразия экосистем. Однако вновь формируемое в результате кризисной перестройки биоразнообразие, как правило, оказывается выше при более плотной упаковке экологических ниш. Предполагается, что кризис помогает преодолевать структурные ограничения роста биоразнообразия в стабилизированной экосистеме, исчерпавшей возможности фрагментации экологических ниш.

\section{К социальной экологии межэтнических сообществ}

Опыт социально-экологической интерпретации взаимодействий этнокультур в составе межэтнического сообщества предпринял известный российский этнолог А. В. Головнев [Головнев, 2015]. Он дифференцировал два типа этнокультур в зависимости от принятой в них модели поведения человека - как «травоядного» или как «хищника». Он же ввел понятие локальных и магистральных этнокультур (таблица).

Признаки локальных и магистральных этнокультур (по А. В. Головневу)

\begin{tabular}{|c|c|c|}
\hline Признак & Локальная этнокультура & Магистральная этнокультура \\
\hline Тип человека & Человек-травоядное (собиратель) & Человек-хищник (охотник) \\
\hline Образ жизни & Оседлость & Кочевничество \\
\hline Культура & $\begin{array}{l}\text { «Возделывает» конкретную } \\
\text { эконишу }\end{array}$ & $\begin{array}{l}\text { Синтезирует локальные группы в сети } \\
\text { коммуникаций и сложные сообщества }\end{array}$ \\
\hline $\begin{array}{l}\text { Уровень } \\
\text { культуры }\end{array}$ & $\begin{array}{c}\text { «Нижняя» культура: собиратели, } \\
\text { промысловики, земледельцы, рыболовы, } \\
\text { ремесленники }\end{array}$ & $\begin{array}{c}\text { «Верхняя» культура: лидеры-посредни- } \\
\text { ки (военно-политическая, жреческая, } \\
\text { торговая элита) }\end{array}$ \\
\hline Технологии & $\begin{array}{c}\text { Бережное отношение к окружающей } \\
\text { среде, культ родного края; детальность } \\
\text { знаний и обстоятельность }\end{array}$ & $\begin{array}{l}\text { Технологии мобильности, } \\
\text { посредничества и экспансии }\end{array}$ \\
\hline $\begin{array}{l}\text { Осваиваемые } \\
\text { ресурсы }\end{array}$ & Биоресурсы & Социоресурсы \\
\hline Адаптация & $\begin{array}{l}\text { Экоадаптация - освоение } \\
\text { конкретного биотопа }\end{array}$ & $\begin{array}{l}\text { Экосоциоадаптация - освоение социо- } \\
\text { культурных ресурсов локальных культур }\end{array}$ \\
\hline $\begin{array}{l}\text { Модель } \\
\text { безопасности }\end{array}$ & «Кормовая» модель безопасности & «Силовая» модель безопасности \\
\hline Компетенции & Умение выживать, устойчивость & $\begin{array}{c}\text { Умение побеждать, } \\
\text { маневренность и эфемерность }\end{array}$ \\
\hline Этничность & «Почвенная» микроэтничность & $\begin{array}{c}\text { Синтетическая макро- и мультиэтнич- } \\
\text { ность }\end{array}$ \\
\hline
\end{tabular}

Источник: таблица составлена на основе обобщения идей А. В. Головнева.

Исторически первичными являются локальные культуры, которые могли существовать и в виде бродячих сообществ. Со стабилизацией природопользования как некие надстроечные структуры возникают магистральные культуры, которые включают в свою 
структуру локальные культуры, расположенные на освоенной магистрали (пути). Например, российскую государственность А.В. Головнев оценивает как возникшую в результате синтеза славянской локальной культуры и трех магистральных культур норманнской, татаро-монгольской, православно-византийской.

Синтез славянской и норманнской культур он описывает так: «Первоначально контакт славян и скандинавов был взаимодействием различных систем адаптации: славянская культура локальных ниш так же органично входила в норманнскую культуру больших пространств, как норманнская торговля и военный промысел дополняли комплекс жизнеобеспечения славян. Эти культуры усиливали друг друга: норманны разными средствами (торговлей, данью, грабежом) собирали “урожай” на славянских землях, а славяне пользовались услугами скандинавов в дальней торговле и военных кампаниях; норманны создавали колонии на славянских землях, а славяне заселяли новые пространства по проторенным скандинавами путям. В сочетании локальной (славянской) и магистральной (норманнской) деятельностных схем сформировалась обширная общность под названием Русь и родилась новая синтетическая норд-русская (верхнерусская, новгородская) культура» [Головнев, 2009. С. 421].

По мнению ученого, взаимодействие магистральных этнокультур лежит в основе появления большинства крупных государств. Релевантность модели А.В. Головнева особенно ярко подтверждается экономической историей государств, образовавшихся в результате колонизаций, основанных на отношениях данничества и подданства, а также функционирующих в режиме неоколониальной зависимости. Российская государственность и в настоящее время опирается на магистральные культуры. Мобильность государствообразующей элиты выражается, в частности, в практике межрегиональной и межотраслевой ротации управленческих кадров.

В экологии используется понятие доминантного вида, наиболее многочисленного в сообществе. В указанном значении русские являются в России доминантным этносом. Но в интерпретации социальной экологии А. В. Головнева русская этнокультура, будучи локальной, оказывается подчинена «хищнической» мультиэтничной магистральной культуре. Этносы - носители последней - с экологической точки зрения относятся к «верховным хищникам». А.В. Головнев различает «нижнюю» и «верхнюю» культуры (напомним, что евразийцы также различали «низы» и «верхи» русской культуры). А в «верхах» исторически заметное место занимали носители магистральных культур - варяги, выходцы из татарской знати, приглашенные на службу немцы, евреи и др., а также те русские, которые ориентированы на обогащение с последующей эмиграцией (западники).

Локальная природа русской культуры определяет невысокий уровень консолидированности этнических русских по сравнению с другими народами России. Для консолидации и самоорганизации русского населения требуется посредничество представителей других, более мобильных этносов, исторически склонных устанавливать и поддерживать связи международного масштаба. Однако умение русских выживать и пластичность русской этнокультуры позволили освоить большую территорию с различными экологическими нишами, адаптироваться к местным, более ригидным этнокультурам и стать ресурсной базой для магистральных элит.

Из экологии известно, что умеренное «хищничество» часто снижает плотность доминантов, давая таким образом возможность менее конкурентоспособным видам лучше использовать пространство и ресурсы [Одум, 1996. С. 135]. Наряду с этим хищник не может ограничиваться одним видом, так как численность последнего неустойчива. Так и экспансия магистральной культуры расширяет территорию, включая другие народы и понижая плотность расселения доминантного этноса. Благодаря этому этнические элиты получают возможность приглашать к себе представителей других этносов, часто специализирующихся на определенных видах хозяйственной деятельности. Поселенцам предоставлялись определенные льготы, привилегии и преференции. Однако в случае ухудшения экономического положения те же льготы и привилегии становились поводом для этнических чисток со стороны коренного населения. Впрочем, дальше вступал в действие экологический принцип «Никто не гибнет в одиночку», и изгнанников, как, например, евреев в средневековой Европе, власти буквально через несколько лет стремились вернуть обратно [The Jews.., 1995. Р. 46-73].

Заметим, что А.В. Головнев характеризует взаимодействие магистральной норманнской и локальной славянской культуры 
в России не только как исключительно отрицательное. Оно было взаимовыгодным и положительным, так как обеспечивало распространение славянской культуры по обширной территории. Похоже, что славянская культура готова сотрудничать с магистральными этнокультурами, если они прокладывают торные пути к новым локальным нишам.

\section{Этнокультура и ландшафт}

Не оправдавшиеся в США надежды на эффект «плавильного котла», а также наметившаяся в современной Европе этническая фрагментация национальных государств и активно проявивший себя общемировой феномен этнического ренессанса актуализировали вопрос о природе и существенных признаках этноса и этнической культуры. В контексте обсуждаемой темы представляет интерес следующее положение В.В. Карлова: «В доиндустриальных обществах, если иметь в виду главные идентификационные признаки на уровне массового сознания, самым основным идентификационным параметром и критерием был прежде всего этнически специфичный для каждого народа способ адаптации к среде обитания, включая все его составляющие, т.е. в первую очередь, всю систему жизнеобеспечения и сами способы этого жизнеобеспечения, характер и способы действий» [Карлов, 2011. С. 470].

Культура этноса адаптивна, прежде всего, по отношению к ландшафту, и эта адаптация осуществляется в процессе трудовой деятельности, таким образом, конкретные параметры местообитания этноса определяют преобладающий хозяйственнокультурный тип. Поэтому логичным представляется качественную специфику этноса выражать через качественную специфику его местообитания.

Как показывает проведенный Я.В. Чесновым анализ этнонимов, многие народы идентифицируют себя по кормящему ландшафту (например, селькуп - «таежный человек») или по способу жизнеобеспечения. Так, степные эвенки назывались мурчены («конные»), а кочующие с оленями - орочел («оленные») [Чеснов, 1982. С. 118].

Формирующиеся этносы имеют хозяйственно-культурные типы, адаптивные к ландшафту, поэтому представители разных этносов по-разному работают и отдыхают, по-разному себя ведут и одеваются, предпочитают особую пищу и т.д. Хозяйственными соображениями обусловлена и устойчивость этнической эндогамии [Бромлей, 1969]. Выбор супруга в своей этнической среде мотивирован экономической целесообразностью общности питания и семейного быта, традиций ведения домашнего хозяйства и адаптивности к типу занятости супруга.

Формируемые адаптивные признаки и умения закрепляются и составляют этнический капитал - этноспецифическую составляющую человеческого капитала этноса. В русской этнокультуре с ее архетипом «всечеловечности» этнокультурному компоненту человеческого капитала чаще всего не придают значения. Но сформированные на протяжении тысячелетий антропологические особенности этнотипа константны. Они не могут быть замещены в процессе воспроизводства человеческой жизни или компенсированы профессиональным образованием. При трудовых миграциях осуществляется определенный отбор подтипов, адаптивных к новому ландшафту, но для этноса это периферийные подтипы, не выражающие антропологический оптимум по отношению к родному ландшафту. Поэтому иногда особые требования, предъявляемые к рабочей силе, вынуждают целенаправленно организовывать миграционные потоки, подобные тем, какие наблюдались в работорговле.

Таким образом, конкретный ландшафт своими особенными природно-климатическими условиями конституирует этническую общность, которая преобразует ландшафт, - и это устойчивое взаимодействие составляет этнокультуру.

Устойчивые модели поведения, исторически сложившиеся в деятельности по освоению и культивированию ландшафта, составляют содержание этнокультурной традиции. Характеризуя значение для современности традиционных хозяйственных практик народов Северного Кавказа, ученые Ю. С. Колесников и Ж. Д. Дармилова [Колесников, Дармилова, 2015. С. 28] обратили внимание на следующие важные, на наш взгляд, моменты. Во-первых, это адаптивность традиционных хозяйственных практик и институтов к ареалу этногенеза. Во-вторых, отмечается императив жизнеобеспечения и выживания этноса, который ориентирован не столько на «эффективность» труда, сколько на соответствие его технологий и приемов, а также всей социальной организации хозяйственных процессов особенностям среды обитания. В-третьих, исторически сформировавшееся социальное закрепление видов и особенностей 
хозяйственных практик, определяющее готовность представителей разных народов к освоению определенных технологий, трудовых навыков, форм организации хозяйственной деятельности. В-четвертых, превращение ландшафтно обусловленных и обеспечивших выживание этноса традиционных моделей хозяйственной деятельности в устойчивые доминанты (константы), определяющие на длительный исторический период инерцию принятия хозяйственных решений представителями этого этноса.

Действительно, если какие-то разумные решения были найдены, то едва ли они должны пересматриваться при неизменности параметров окружающей среды. Поэтому модернизация должна учитывать этнокультурную традицию. Известным примером такой исторической практики является успешное развитие капитализма в Японии. В инновационном развитии необходимо использование традиций как магистралей устойчивого развития. Уход с магистрали возможен, но при стабильности условий окружающей среды неизбежно возвращение на магистраль как траекторию, на которой за длительное время достигается максимальная скорость экономического роста.

\section{«Разноцветная" экономика:}

\section{возможен ли этнодизайн?}

Для описания идеальной модели экономики, оптимизирующей этнокультурное разнообразие, В.А. Крюков предложил метафору «разноцветной» экономики. «В процессе “движения” народов (их культур и хозяйственных укладов) на различных территориях формируются соотношения подходов к ведению хозяйственной деятельности, отличающиеся от преобладавших на данной территории ранее, - пишет он. - В этом случае экономика становится все более "разноцветной” - меняются не только виды хозяйственной деятельности, но и, что не менее важно, те отношения, которые ее опосредуют. Последние все в большей степени “окрашиваются" в национальные цвета и краски тех народов и культур, которые они с собой приносят и которых они придерживаются...» [Крюков, 2017. С. 2].

Действительно, визуальные метафоры многоцветности, мозаики, радуги культуры часто используются для описания этнокультурных праздников и выражения позитивного образа межэтнических сообществ. Однако перенос цветовых метафор на экономическую жизнь требует разрешения ряда затруднений. Во-первых, нет однозначности в цветовой идентификации культур. Во-вторых, определенные сложности создают устоявшиеся метафоры цветовых значений. Так, черно-белая метафора традиционно применяется для обозначения легальности / нелегальности хозяйственной деятельности, а метафоры «синей», «зеленой» и «коричневой» экономики используются в рамках ее экологически ориентированной оценки.

Если же предпринять опыт цветовой идентификации российской экономики, то можно обратить внимание, что жизнь в России обычно ассоциируется с серым цветом: серое небо, серые будни, серый быт, серая масса населения, серость как обеспечивающий выживание антропологический оптимум. Нормой является и серая экономика - так называемая псевдоэкономика, не столько скрываемая, сколько имитативная хозяйственная деятельность, хотя и теневая экономика даже по официальным данным составляет сейчас в России более шестой доли ВВП.

Серый цвет нейтрален, обезличен и практичен. Известно, что он не привлекает к себе внимание, легко сочетается с другими цветами и служит для них идеальным фоном, все цвета выступают на нем в их действительном звучании.

В экономической интерпретации это означает, что русская экономическая культура - это культура повседневного, незаметного и спокойного, умеренного и нелихорадочного труда. Труда служебного, когда служат и помогают всем, не выпячивая свое «Я», а наоборот, выделяя и подчеркивая достижения других, возможно, более «ярких» этнокультур.

\section{Заключение}

В последнее время на уровне представительных международных организаций этнокультурное многообразие признано в качестве важного условия жизнеспособности социума, подобно оценке роли биоразнообразия для устойчивости экосистем и биосферы в целом. В вопросе о связи этнокультурного многообразия и экономического развития, этнокультуры и экономики осознана необходимость объединения «лучших черт и особенностей экономических укладов», базирующихся на разных этнических традициях, с целью формирования «синтетического»уклада «на основе различных культур и хозяйственных практик» [Крюков, 
2017. С. 2]. Такая установка задает важные методологические ориентиры в изучении данной темы для представителей социально-философской, социологической, культурологической, этнологической, конфликтологической, экономической наук.

Мы обозначили некоторые значимые, на наш взгляд, вопросы, в совокупности составляющие концептуальные предпосылки для успешной разработки рассматриваемой темы. Перспективная задача состоит в том, чтобы от общей постановки и обоснования проблемы перейти к содержательному анализу конкретных процессов. И здесь хотелось бы обратить внимание на существующую проблемную ситуацию.

С учетом того, что этнокультурное многообразие во многом является продуктом миграционных процессов, можно констатировать наличие в социогуманитарных науках двух векторов научных поисков, противоположных в своих оценках происходящего. С одной стороны, позитивно оценивается роль этнокультурного многообразия для динамизма и устойчивости экономики, прежде всего в аспекте предпринимательской деятельности [Цапенко, 2016]. С другой - акцентируется негативное влияние современных миграционных процессов на состояние межэтнических отношений как в глобальном, так и в региональном масштабах Поэтому одним из перспективных направлений исследований должно стать комплексное осмысление экономических и этносоциальных последствий усиления этнокультурного разнообразия под влиянием миграционных процессов, выявление тех условий и механизмов, при которых экономические выгоды одновременно являются благоприятными для межэтнического сообщества, укрепления его интеграционного потенциала.

\section{Литература}

Бромлей Ю.В. Этнос и эндогамия // Советская этнография. 1969. № 6. C. $84-91$.

Буфетова А.Н., Коломак Е.А., Михалёва М.М. Национальное разнообразие и экономическое развитие регионов России // Мир экономики и управления. 2017. № 3. С. $143-157$.

Виноградова Ю.К., Майоров С.Р., Бочкин В. Д. Влияние чужеродных видов растений на динамику флоры территории Главного ботанического сада РАН // Российский журнал биологических инвазий. 2015. № 4. С. 22-41.

Головнёв А. В. Локальные и магистральные культуры Северной Евразии // Человек и Север: антропология, археология, экология: Материалы всероссий- ской конференции. Тюмень: Изд-во Ин-та проблем освоения Севера СО РАН, 2012. C. 234-237.

Головнёв А.В. Антропология движения (древности Северной Евразии). Екатеринбург: УрО РАН; «Волот», 2009. 496 с.

Горшков В.Г. Физические и биологические основы устойчивости жизни. ВИНИТИ, 1995. $494 \mathrm{c.}$

Камалова Р. У. Этническая гетерогенность: основные понятия и проблемь измерения // Полития. 2013. № 4. С. 127-149.

Карлов В. В. Этническая идентификация в системе идентичностей глобального мира: тенденции изменений // Феномен идентичности в современном гуманитарном знании: к 70-летию академика В.А. Тишкова. М.: Наука, 2011 C. $469-473$.

Козлов В.И. Этнос и экономика. Этническая и экономическая общности // Советская этнография. 1970. № 6. С. 47-60.

Козлов В.И. Этническая экология: становление дисциплины и история проблем. М.: Институт этнологии и антропологии РАН, 1994. 230 с.

Колесников Ю. С., Дармилова Ж.Д. Традиционные хозяйственные практики народов Северного Кавказа и современность // Вестник Адыгейского государственного университета. Сер. 5: Экономика. 2015. Вып. 4. С. 26-39.

Крюков В. А. «Разноцветная» экономика // ЭКО. 2017. № 10. С. 2-4.

Лист $\Phi$. Национальная система политической экономии. М.: Издательство «Европа», 2005. 382 c.

Милль Дж.С. Основы политической экономии и некоторые аспекты их приложения к социальной философии. Т. 1. М.: Прогресс, 1980. 495 с.

Одум Ю. Экология: В 2-х т. Т. 2. Пер. с англ. М.: Мир, 1986. 376 с.

Павлов К. В. Этноменеджмент как составная часть этноэкономики // Вестник Института экономических исследований. 2016. № 2. С. 13-28.

Рикардо Д. Начала политической экономии и налогового обложения // Рикардо Д. Соч. М.: Государственное издательство политической литературы, 1955. С. $30-360$.

Семенов Ю.И. Экономическая этнология: М.: Институт этнологии и антропологии РАН, 1993. 710 с.

Смит А. Исследование о природе и причинах богатства народов. М.: Издательство социально-экономической литературы, 1962. 684 с.

Цапенко И. Экономические ресурсы этнокультурного разнообразия // Мировая экономика и международные отношения. 2016. № 11. С. 35-46.

Чеснов Я.В. Об этнической специфике хозяйственно-культурных типов Этнос в доклассовом и раннеклассовом обществе. М.: Наука, 1982. С. 109-124. Light I. The ethnic economy. In: N.J. Smelser and R. Swedberg, eds. The handbook of economic sociology. Princeton: Princeton University Press, 1994. P. $650-677$.

The Jews in Western Europe 1400-1600. Manchester and New York: Manchester University Press, 1995. 156 p.

Статья поступила 02.03.2018. 


\section{Summary}

Popkov Yu. V., Institute of Philosophy and Law, SB RAS, Novosibirsk State Technical University, Novosibirsk; Tiugashev E. A., Novosibirsk National Research State University, Novosibirsk.

\section{The Ethnic Culture and Economy: Synergy Opportunities}

The article presents an overview of the conceptual prerequisites for the study of the relationship of ethno-cultural diversity with the social mechanisms of economic life. It highlights the ideas of classical political economy on the subject with the emphasis on "nation-centeredness" that establishes the defining influence of climatic conditions, type of economy, cultural specifics and features of national character of the population on the economic specialization of nations. Ethno-cultural diversity is viewed as an additional economic resource. It also singles out the ecological and economic concepts of stability and productivity of ecological communities, which are used to interpret the role of ethno-cultural diversity in the socio-economic development of interethnic communities and ensure their social stability and economic productivity. The analysis of the geographically localized economy as an interethnic community allows to conclude that ethno-cultural diversity has a beneficia effect on the economic development and interethnic relations, provided successful integration of other non-ethno-cultural groups into the host community is achieved.

Ethnic group; ethnic diversity" ethnic culture; ethnic economics; ethnic ecology; anthropo-ecology» interethnic community

\section{References}

Bromlej Yu.V. (1969). Etnos i endogamiya. Sovetskaya etnografiya [Soviet Ethnography]. No. 6. Pp. 84-91. (In Russ.)

Bufetova A. N., Kolomak E.A., Mihalyova M. M. (2017). Nacional'noe raznoobrazie i ehkonomicheskoe razvitie regionov Rossii. Mir ehkonomiki i upravleniya [World of economics and management]. No. 3. Pp. 143-157. (In Russ.)

Vinogradova Yu.K., Mayorov S. R., Bochkin V.D. (2015). Vliyanie chuzherodnih vidov rastenii na dinamiku flori territorii Glavnogo botanicheskogo sada RAN Rossijskij zhurnal biologicheskih invazii [Russian Journal of Biological Invasions]. No. 4. Pp. 22-41. (In Russ.)

Golovnyov A. V. (2009). Antropologiya dvizheniya (drevnosti Severnoj Evrazii). Ekaterinburg, UB Publ., Volot Publ. 496 p. (In Russ.)

Golovnyov A. V. (2012). Lokal'nie i magistral'nie kul'turi Severnoi Evrazii. In: Chelovek i Sever. Antropologiya, arheologiya, ekologiya: Materialy vserossiiskoi konferencii [Man and the North. Anthropology, archeology, ecology: Materials of the all-Russian conference]. Tyumen. Pp. 234-237. (In Russ.)

Gorshkov V. G. (1995). Fizicheskie i biologicheskie osnovi ustoichivosti zhizni. VINITI Publ. 494 p. (In Russ.)

Kamalova R.U. (2013) Etnicheskaya geterogennost': osnovnye ponyatiya i problemy izmereniya. Politiya [Politeia]. No. 4. Pp. 127-149. (In Russ.)

Karlov V.V. (2011). Etnicheskaya identifikaciya v sisteme identichnostej global'nogo mira: tendencii izmenenij. In: Fenomen identichnosti v sovremennom gumanitarnom znanii: k 70-letiyu akademika V.A. Tishkova [The phenomenon of identity in contemporary humanitarian knowledge: to the 70th birthday of Academician V.A. Tishkov]. Moscow. Nauka Publ. Pp. 469-473. (In Russ.)
Kozlov V.I. (1970). Etnos i ehkonomika. Etnicheskaya i ehkonomicheskaya obshchnosti. Sovetskaya etnografiya [Soviet Ethnography]. No. 6. Pp. 47-60 (In Russ.)

Kozlov V.I. (1994). Etnicheskaya ehkologiya: stanovlenie discipliny i istoriya problem. Moscow. Institut ehtnologii i antropologii RAN Publ. 230 p. (In Russ.)

Kolesnikov Yu.S., Darmilova Zh.D. (2015). Tradicionnye hozyaistvennye praktiki narodov Severnogo Kavkaza i sovremennost'. Vestnik Adygejskogo gosudarstvennogo universiteta [The Bulletin of Adyghe State University]. Series. 5: Economics. Vol. 4. Pp. 26-39. (In Russ.)

Kryukov V.A. (2017). «Raznocvetnaya» ehkonomika. ECO [ECO]. No. 10. Pp. 2-4. (In Russ.)

List F. (2005). Nacional'naya sistema politicheskoj ehkonomii. Moscow. Evropa Publ. 382 p. (In Russ.)

Mill' Dzh. S. (1980). Osnovy politicheskoj ehkonomii i nekotorye aspekty ih prilozheniya k social'noi filosofii. Vol. 1. Moscow. Progress Publ. 495 p.

Odum Yu. (1986). Ekologiya. Vol. 2. Moscow. Mir Publ. 376 p. (In Russ.)

Pavlov K. V. (2016). Etnomenedzhment kak sostavnaya chast' etnoehkonomiki. Vestnik Instituta ehkonomicheskih issledovanij [Vestnik of Institute of Economic Research]. No. 2. Pp. 13-28. (In Russ.)

Rikardo D. (1955). Nachala politicheskoi ekonomii i nalogovogo oblozheniya. In: Rikardo D. Sochineniya [Compositions]. Gosudarstvennoe izdatel'stvo politicheskoj literatury Publ. Pp. 30-360. (In Russ.)

Semenov Yu.I. (1993). Ekonomicheskaya ehtnologiya. Moscow. Institut ehtnologii i antropologii RAN Publ. 710 p. (In Russ.)

Smit A. (1962). Issledovanie o prirode i prichinah bogatstva narodov. Moscow. Izdatel'stvo social'no-ekonomicheskoi literaturi Publ. 684 p. (In Russ.)

Capenko I. (2016). Ekonomicheskie resursy etnokul'turnogo raznoobraziya. Mirovaya ehkonomika i mezhdunarodnye otnosheniya [World Economy and International Relations]. No. 11. Pp. 35-46. (In Russ.)

Chesnov Ya.V. (1982). Ob ehtnicheskoi specifike hozyajstvenno-kul'turnih tipov. In: Etnos $v$ doklassovom i ranneklassovom obshchestve [Ethnos in pre-class and early class society]. Moscow. Nauka Publ. Pp. 109-124. (In Russ.)

Light I. (1994). The ethnic economy. In: N. J. Smelser and R. Swedberg, eds. The handbook of economic sociology. Princeton: Princeton University Press. Pp. 650-677.

The Jews in Western Europe 1400-1600. (1995). Manchester and New York: Manchester University Press. 156 p. 